\title{
Analysis of Students' Science Literacy Ability on Heat Concept
}

\author{
Anderias Henukh ${ }^{1}$, Merta Simbolon ${ }^{2}$, I Made Astra ${ }^{3}$, Haris Rosdianto ${ }^{4}$ \\ Universitas Musamus, Indonesia ${ }^{1,2}$, Universitas Negeri Jakarta, Indonesia ${ }^{3}$, STKIP Singkawang, \\ Indonesia ${ }^{4}$ \\ henukh_fkip@unmus.ac.id ${ }^{1}$, simbolon_fkip@unmus.ac.id ${ }^{2}$,imadeastra@unj.ac.id ${ }^{3}$, \\ harisrosdianto@yahoo.com ${ }^{4}$
}

Received: November $27^{\text {th }}, 2020$. Revised: February $19^{\text {th }}, 2021$. Accepted: February $24^{\text {th }}, 2021$

\section{Keywords : \\ Literacy; Science Literacy; \\ STEM; Heat Concept}

\begin{abstract}
This study aims to describe the scientific literacy skills of students where the results can be used as a basis for implementing learning with the STEM approach based on local wisdom of Papua. This research was conducted at SMP YPPK St. Mikael Merauke in class VIII SMP students, especially in the heated material. This research uses a descriptive quantitative method. The instrument used in this study was multiple-choice totaling 30 numbers based on scientific literacy. The research instrument used has gone through a validation process and is declared valid. The results of the data analysis showed that the scientific literacy skills of students on the indicator of understanding scientific phenomena obtained an average score of $66 \%$. The indicator explaining scientific phenomena obtains an average score of $62 \%$. In the scientific problem identification indicator, the average score obtained is $65 \%$. However, on the indicators of interpreting the data and scientific evidence the average score obtained was 59\%. In the domain of scientific literacy, the aspect of scientific knowledge obtained an average score of 66\%. Likewise in the scientific competency aspect, the average score obtained is $62 \%$. Based on the results of the data analysis, it can be concluded that the overall score of students' scientific literacy skills is in a good category.
\end{abstract}

\section{INTRODUCTION}

The development of the era before humans existed until now continues to experience increasingly rapid changes. The development of industry in the 21st century is increasingly unstoppable due to advances in science and technology that play a role in meeting human needs [1] [2]. The massive progress of industry in the 21 st century also causes many political, economic, social, cultural, and environmental problems. For example, the problem of increasing the earth's temperature, environmental damage, energy emergencies, economic emergencies, and frequent disputes between groups [3]. 
All of the above problems can occur due to a lack of understanding of science. We always use science and technology to explore the environment without thinking about the consequences for the environment and the future of the planet we inhabit. Scientific literacy plays a major role in navigating the various demands of the 21 st century in terms of human efforts to meet basic needs, control diseases, produce adequate energy and increase the earth's temperature. This requires students to have scientific literacy abilities in the era of the industrial revolution 4.0 [4].

Based on the views of the Organization for Economic Co-operation and Development in 2003, scientific literacy is the ability to apply scientific knowledge, recognize questions, and make conclusions according to facts, to interpret and make decisions relating to the biotic environment through the activities of each individual [5]. The PISA survey examined 15-year-old adolescents from OECD countries to measure learning ability through a series of tests. According to data published by the OECD from the 2009-2015 survey period, Indonesia consistently ranks in the bottom 10. Of the three competency categories, Indonesia's scores are always below the average. The results of the 2009-2018 PISA survey put Indonesia at the bottom of the list, the scores obtained by students were still below average. Based on the existing data, it also shows that there has been an increase and decrease in the achievement of the PISA scientific abilities of Indonesian students who are in the 393,383, 382, 403 rank in the 2005-2015 period. The score of scientific ability experienced a decline in the 2018 PISA exposure, namely 396 [6].

The results of previous reviews that have been carried out previously show that the scientific literacy abilities of students on the island of Java are in a category that is close to the PISA average score [4] [5]. When comparisons with PISA products are carried out, a representation is obtained that the education of each region in Indonesia, including Papua, experiences differences in quality. This can be seen as an impetus to analyze the extent to which the scientific literacy abilities of students in the Papua region, especially at SMP YPPK Santo Mikael, Merauke Regency so that efforts to overcome them with a STEM approach based on local wisdom can be successful.

The Science, Technology, Engineering, and Mathematics (STEM) approach is an approach that combines various disciplines, namely science, technology, technic, and mathematics. This collaboration will help students to collect and describe and find solutions to existing problems and be able to find out the relationship between a problem and another problem [7] [8].The STEM approach is based on the ability of students to apply their knowledge of how rivalry works in the real world which requires four interrelated aspects [9]. The application of STEM in learning activities consists of creativity, critical thinking, collaboration, and communication so that students can find innovative solutions to the obstacles faced factually . Learning with this approach can help students find case solutions and make conclusions from previous learning by applying them to science, technology, engineering, and mathematics [10] [11].

Local wisdom is part of the culture of a society that is inseparable from the community itself. A knowledge that is found by certain local communities through a collection of experiences in trying and integrated with an understanding of the local culture and natural environment. Local culture is all systems of ideas, deeds, and all human works in the context of social life. How to learn Science-based learning with integration is a way to preserve the community's culture which is beginning to be endangered and to bring them closer to science in everyday life because the culture is an inseparable part. separated from education, culture is something that must be learned and integrated so that it is useful for society [12]. Previous research suggests that local wisdom-based learning adapted to the conditions of students in the surrounding area can help teachers in teaching their students. In addition, it was also argued that local wisdom-based learning could improve students' scientific literacy abilities [13].

Following the results of the review above, research will be carried out related to the analysis of students' scientific literacy abilities as an effort to implement the STEM approach based on local wisdom of Papua. The formulation of the problem is what is the scientific literacy ability of students of SMP YPPK 
Santo Mikael? The purpose of this research is to describe the scientific literacy abilities of students so that efforts to apply the STEM approach based on local wisdom of Papua can provide maximum results.

\section{METHOD}

This research was conducted at SMP YPPK St Mikael, Merauke Regency to 50 grade VIII students. This type of research used in this research is descriptive quantitative research. The research instrument used in this study was a multiple choice question totaling 30 numbers with four valid answer choices so that it was suitable for use in data collection. The data obtained is quantitative data which will be analyzed using descriptive statistical analysis. The results of the analysis will then be processed qualitatively by doing descriptive data. Then in the final stage, conclusions are drawn based on the results of the data analysis [14] [15].

Table 1. Interpretation of the Scores Obtained

\begin{tabular}{cc}
\hline The Average score $(\%)$ & Interpretation score \\
\hline$\leq 20$ & Bad \\
$21-40$ & Not good \\
$41-60$ & Enough \\
$61-80$ & Good \\
$81-100$ & Very good \\
\hline
\end{tabular}

\section{RESULTS AND DISCUSSIONS}

The results of the study were related to the analysis of students' scientific literacy abilities, especially in the heated material as an effort to implement the STEM approach based on Papuan local wisdom at SMP YPPK St. Mikael Merauke can be described as follows. The results of the material expert instrument validation can be described as follows.

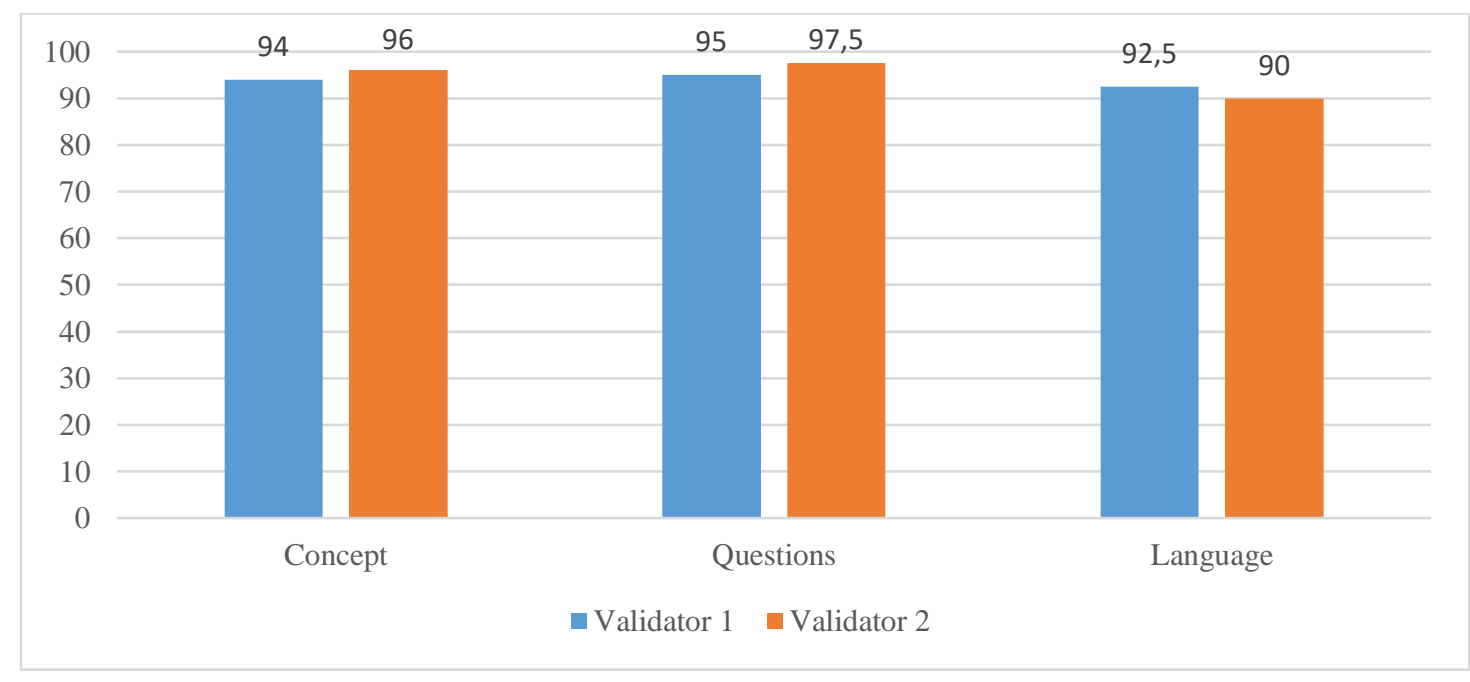

Fig 1. Concept Expert Validation Results

Based on the results of the material experts above, it is known that the scores obtained in the material aspect of each validator are 94 and 96, so the average is 95 , thus the material aspect is in the very feasible category. In the question aspect, the scores obtained from each validator were 95 and 97.5 so that the average was 96.5 and was in the very feasible category. The language aspects that are validated by the validator get a score of 92.5 and 90 so that the average is 91.25 and can be interpreted as a very feasible category. However, suggestions are given to improve some punctuation marks and typos on the prepared 
instrument. Following the validation results obtained, the instruments provided are suitable for retrieving data.

The measurement of students' scientific literacy abilities which includes 4 indicators of scientific literacy and 2 domains can be seen in Figure 2 below.

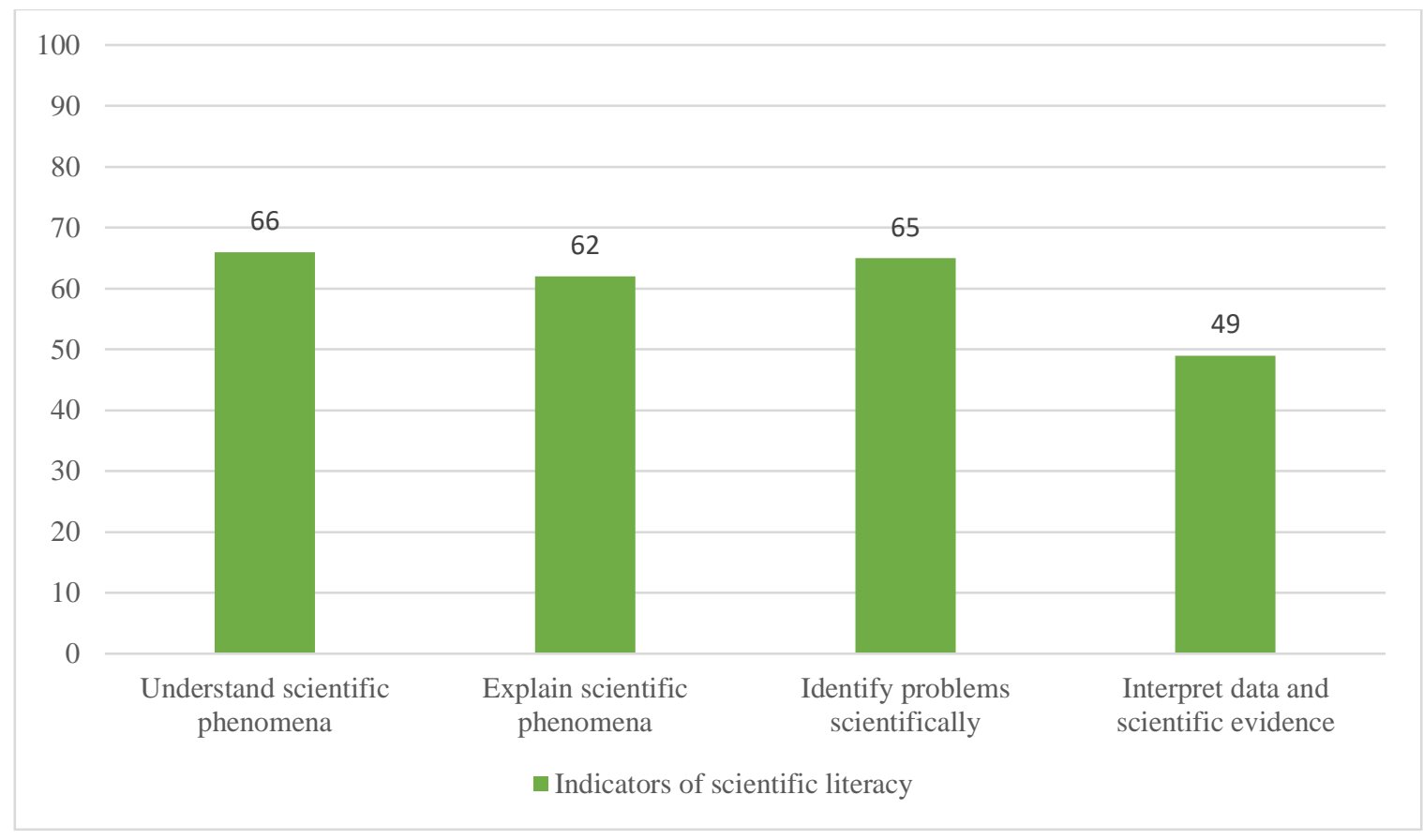

Fig 2. The Results Of The Analysis Of Scientific Literacy Indicators

Based on the data obtained in the image above, it shows that the indicators of understanding scientific phenomena the average score obtained by students are $66 \%$. The score obtained can be interpreted as a good category. The indicator explaining the scientific phenomenon obtains an average score of $62 \%$ so that it can be interpreted as a good category. Likewise, in the indicator of identifying problems scientifically, the average score obtained is $65 \%$ so that it can be interpreted as a good category. However, on the indicators of interpreting data and scientific evidence the average score obtained is $49 \%$ so that it can be interpreted as a fairly good category.

The domain aspects of scientific literacy can be seen in Figure 3 below.

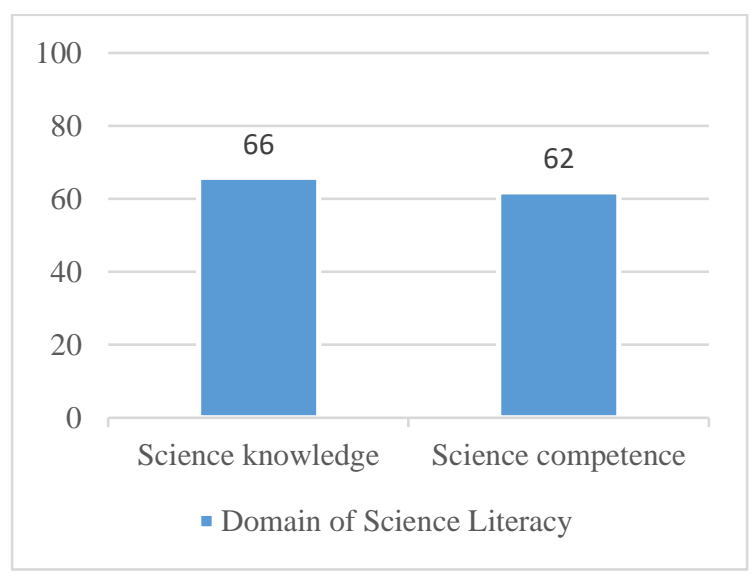

Fig 3. The Results Domain Of Science Literacy 
Following Figure 3 above, the domain of scientific literacy in the aspect of scientific knowledge, the average score obtained is $66 \%$, so it is interpreted as a good category. Likewise, in the domain of scientific competence the average score obtained is $62 \%$ so that it is interpreted as a good category.

The results showed that students had good scientific literacy skills in the domain of scientific knowledge. This result is in line with previous research regarding the analysis of students' scientific literacy skills in terms of physics problem-solving abilities at SMAN 2 Bulukumba which explains that having a greater percentage of truth in aspects of scientific knowledge makes an important contribution to their scientific literacy skills [16]. Likewise in other studies found that students were better at memorizing than scientific processing skills. This is related to the tendency of students to master knowledge using rote rather than thinking skills. Another cause is the habit of learning science in schools which prioritizes cognitive aspects rather than developing students' thinking abilities [5] [17]. In the teaching and learning process in schools, the way teachers teach plays an important role in improving student learning outcomes. If a teacher in teaching is guided by the dimensions of good teaching dimensions, it will lead to a good perception of students, so that in the end the teacher is said to be successful in educating students because it creates a good impression from students. Science literacy skills of students will develop well if science educators can master science learning materials and methods well. Students' scientific literacy is very important to be developed to have high competitiveness in facing the current era of information technology and in the future which is marked by increasingly fierce global competition.

The scientific literacy abilities of students on indicators of explaining scientific phenomena as a whole are in the good category. The results of this study are also following previous research [18]. The achievement of the competency aspect of the indicator explaining scientific phenomena shows that students have taken the time to learn science and enjoy learning science so that the achievement of scientific explanations or explaining scientific phenomena is better [19] [20]. Likewise, in the indicators of identifying problems scientifically the scores obtained are in the good category.

The results of this study can be a reference for junior high school science teachers to develop students 'scientific literacy abilities by applying learning models that can improve students' scientific literacy abilities, including STEM-based learning. Whereas in the indicators of interpreting data and scientific evidence, the students' scores are quite good. These results provide evidence that there is a need to improve the learning process, such as findings in previous studies which show that in general students still have difficulty interpreting scientific data and evidence [7] [21]. Overall the results of the analysis of students' scientific literacy abilities were in the good category in the two domains tested, but it should also be noted that these results were influenced by several other variables that could not be controlled by the research team because the research instruments were given to students to be done independently in their respective homes. This was done because of the learning program from home by the government of the Republic of Indonesia due to Covid-19.

It is realized that the results of the research have not been able to describe the scientific literacy abilities of students in Merauke as a whole, but research can be used as a preliminary research to get an overview in designing learning and learning concept that support the application of STEM based on Papuan local wisdom. This is in line with previous research which states that learning using the STEM (Science, technology, engineering and mathematics) approach is an effort to improve learning, especially in elementary school students' science literacy abilities, how students can understand the environment and problems faced by modern society. which is very dependent on the development of science and technology, including social problems, so that by using the STEM approach the learning process will be more varied and innovative so that it can learn various academic concepts juxtaposed with the real world. STEM learning can help students acquire complete knowledge, be more skilled in dealing with real-life problems and develop students' critical thinking [22]. 


\section{CONCLUSION AND SUGGESTION}

Based on the results of the data analysis and the discussion above, it is known that the scientific literacy abilities of class VIII students on the heat concept as a whole are in a good category. This indicates that the learning process at the school has been going well, but it is necessary to increase the learning process so that it gets better results. As previously described, the research took place during the Covid-19 period so that there were other variables that the researcher could not control. However, the data obtained can be used as a reference in designing STEM-based learning concept that support the improvement of students' scientific literacy, especially in Papua.

\section{ACKNOWLEDGMENTS}

We would like to thank Musamus University for funding this research through internal funds in 2020. Hopefully, this research can be useful for the development of science and can be used as initial data for further research, in the field of science, especially in physics education.

\section{REFERENCES}

[1] Henukh, A., Nikat, R. F., Simbolon, M., Nuryadin, C., \& Baso, Y. S. (2019, October). Multimedia development based on web connected Massive Open Online Courses (cMOOCs) on the basic physics material. In IOP Conference Series: Earth and Environmental Science (Vol. 343, No. 1, p. 012160). IOP Publishing.

[2] Henukh, A., Rosdianto, H., \& Oikawa, S. (2020). Implementation of Google Classroom as Multimedia Learning. JIPF (Jurnal Ilmu Pendidikan Fisika), 5(1): 38-44.

[3] Fananta, M. R. (2017). Materi Pendukung Literasi Sains. Jakarta [Online]. Available: https://gln.kemdikbud.go.id/glnsite/wp-content/uploads/2017/10/cover-materi-pendukungliterasi-sains-gabung.pdf.

[4] Alcamo, J., Fernandez, N., Leonard, S. A., Peduzzi, P., Singh, A., \& Harding Rohr Reis, R. (2012). 21 issues for the 21st Century: results of the UNEP Foresight Process on Emerging Environmental issues.

[5] Sukowati, D., Rusilowati, A., \& Sugianto, S. (2017). Analisis kemampuan literasi sains dan metakogntif peserta didik. Physics Communication, 1(1): 16-22.

[6] Diana, S., Rachmatulloh, A., \& Rahmawati, E. S. (2015). Profil Kemampuan Literasi Sains Siswa SMA Berdasarkan Instrumen Scientific Literacy Assesments (SLA). In Seminar Nasional XII Pendidikan Biologi FKIP UNS (Vol. 201).

[7] Murti, P. R., \& Aminah, N. S. (2018, September). The Analysis of High School Students' Science Literacy Based on Nature of Science Literacy Test (NOSLiT). In Journal of Physics: Conference Series (Vol. 1097, No. 1, p. 012003). IOP Publishing.

[8] Fikri, M. R., Muslim, M., Purwana, U., \& Karyawan, K. (2019). Upaya Meningkatkan Kreativitas Siswa Dalam Membuat Karya Fisika Melalui Model Pembelajaran Berbasis STEM (Science, Technology, Engineering and Mathematics) Pada Materi Fluida Statis. WaPFi (Wahana Pendidikan Fisika), 4(1): 73-76.

[9] Winarni, J., \& Zubaidah, S. (2016). STEM: ApaM mengapa, dan Bagaimana. In Seminar Nasional Pendidikan IPA Pascasarjana UM.

[10] Afifah, A. N., Ilmiyati, N., \& Toto, T. (2019). Model Project Based Learning (PjBL) Berbasis STEM Untuk Meningkatkan Penguasaan Konsep Dan Keterampilan Berpikir Kritis Siswa. Quagga: Jurnal Pendidikan dan Biologi, 11(2): 73-78.

[11] Wahyuaji, N. R., \& Suparman, S. (2019, January). Deskripsi Kebutuhan Media Pembelajaran Elearning Berpendekatan STEM Untuk Mengembangkan kemampuan Berpikir Kritis dan Kreatif Siswa SMA Kelas XI. In Seminar Nasional Pendidikan Matematika Ahmad Dahlan (Vol. 6).

[12] Sari, J. R., Kartimi, K., \& Fitriah, E. (2015). Penerapan pembelajaran biologi berbasis sains budaya lokal kesenian sintren pada konsep spermatophyta untuk meningkatkan keterampilan berpikir kritis 
siswa SMAN 1 Ciwaringin. Scientiae Educatia: Jurnal Pendidikan Sains, 4(1): 11-20.

[13] Sapitri, R. D., Hadisaputra, S., \& Junaidi, E. (2020). Pengaruh penerapan praktikum berbasis kearifan lokal terhadap keterampilan literasi sains dan hasil belajar. Jurnal Pijar Mipa, 15(2): 122129.

[14] Henukh, A., \& Guntara, Y. (2020). Analyzing the response of learners to use kahoot as gamification of learning physics. Gravity: Jurnal Ilmiah Penelitian dan Pembelajaran Fisika, 6(1): 72-76.

[15] Henukh, A., Utomo, M. E., Nikat, R. F., Reski, A., Simbolon, M., \& Asmal, S. (2020, March). Development of practical tools faraday effects on magnetic materials. In IOP Conference Series: Earth and Environmental Science (Vol. 473, No. 1, p. 012137). IOP Publishing.

[16] Irwan, A. P., Usman, U., \& Amin, B. D. (2019). Analisis Kemampuan Literasi Sains Peserta Didik Ditinjau Dari Kemampuan Menyelesaikan Soal Fisika Di SMAN 2 Bulukumba. Jurnal Sains Dan Pendidikan Fisika, 15(3): 17-24.

[17] Jamaluddin, J., Jufri, A. W., Ramdani, A., \& Azizah, A. (2019). Profil Literasi Sains Dan Keterampilan Berpikir Kritis Pendidik Ipa Smp. Jurnal Penelitian Pendidikan IPA, 5(1).

[18] Pratiwi, S. N., Cari, C., \& Aminah, N. S. (2019). Pembelajaran IPA abad 21 dengan literasi sains siswa. Jurnal Materi dan Pembelajaran Fisika, 9(1): 34-42.

[19] Rohmah, U. N., Ansori, Y. Z., \& Nahdi, D. S. (2019, October). Pendekatan Pembelajaran Stem Dalam Meningkatkan Kemampuan Literasi Sains Siswa Sekolah Dasar. In Prosiding Seminar Nasional Pendidikan (Vol. 1, pp. 471-478).

[20] Arifin, L., \& Sunarti, T. (2017). The Improvement Of Students' Scientific Literacy Through Guided Inquiry Learning Model On Fluid Dynamics Topic. Jurnal Penelitian Fisika Dan Aplikasinya (JPFA), 7(2): 68-78.

[21] Fakhriyah, F., Masfuah, S., Roysa, M., Rusilowati, A., \& Rahayu, E. S. (2017). Student's Science Literacy in the Aspect of Content Science?. Jurnal Pendidikan IPA Indonesia, 6(1): 81-87.

[22] Yuliati, Y., \& Saputra, D. S. (2019). Urgensi Pendidikan STEM terhadap Literasi Sains Mahasiswa Calon Guru Sekolah Dasar. Proceedings of the ICECRS, 2(1): 321-326. 